\title{
Estimating shadow prices and efficiency analysis of productive inputs and pesticide use of vegetable production
}

\author{
Alphonse G. Singbo ${ }^{\mathrm{a}, \mathrm{b}, \mathrm{c}, \mathrm{d}, *, \text {, Alfons Oude Lansink }}{ }^{\mathrm{c}}$, Grigorios Emvalomatis ${ }^{\mathrm{e}}$ \\ a International Crops Research Institute for the Semi-Arid Tropics, ICRISAT, BP 320, Bamako, Mali \\ ${ }^{\mathrm{b}}$ Laval University, CREATE, 2425 Rue de l'Agriculture, Pavillon Paul Comtois, Quebec, G1V 0A6 Quebec, Canada \\ ${ }^{c}$ Business Economics Group, Department of Social Sciences, Wageningen University, Hollandseweg 1, 6706 KN Wageningen, The Netherlands \\ ${ }^{\mathrm{d}}$ Programme Analyse de la Politique Agricole (PAPA), Institut National des Recherches Agricoles du Benin (INRAB), 01 P.O. Box 128, Porto-Novo, Benin

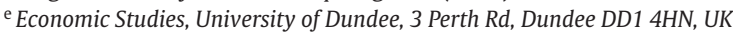

\section{A R T I C L E I N F O}

Article history:

Received 14 June 2013

Accepted 23 February 2015

Available online 5 March 2015

\section{Keywords:}

Input specific efficiency

Shadow prices

Smooth bootstrap

Pesticides

Vegetables

\begin{abstract}
A B S T R A C T
This paper analyzes technical efficiency and the value of the marginal product of productive inputs vis-avis pesticide use to measure allocative efficiency of pesticide use along productive inputs. We employ the data envelopment analysis framework and marginal cost techniques to estimate technical efficiency and the shadow values of each input. A bootstrap technique is applied to overcome the limitations of DEA and helps to estimate the mean and 95 percent confidence intervals of the estimated quantities. The methods are applied to a sample of vegetable producers in Benin over the period 2009-2010. Results indicated that bias corrected technical efficiency scores are lower than the initial measures and the former estimates are statistically significant. The application results show that vegetable producers are less efficient with respect to pesticide use than other inputs. Also, results suggest that pesticides, land and fertilizers are overused.
\end{abstract}

(C) 2015 Elsevier B.V. All rights reserved.

\section{Introduction}

Unlike productive inputs (e.g. fertilizers or improved crop varieties) which have a more straightforward relationship with higher productivity and for which there are well-established methods and models that can be used to predict their effect on crop yields, pesticides do not have a direct impact on crop yields, other than limiting the possible adverse effects of pests, and are extremely diverse with nearly a thousand active ingredients currently in use. Vegetable production is impacted by the presence of large range of insects, implying increasing use of pesticides. Williamson, Ball, and Pretty (2008) indicated that the relative costs of pesticides have risen sharply in recent years, implying that farmers continuously need to adapt the use of pesticides in order to avoid over- or under use. Insights in the value of the marginal product (VMP) of pesticides in vegetable production and the impact of other inputs on the VMP of pesticides can help in determining the optimal use of pesticides.

Parametric and non-parametric approaches have been used to study the value of the marginal product of pesticides. Oude Lansink and Carpentier (2001) and Skevas, Stefanou, and Oude Lansink (2013) adopted a parametric approach to measuring the VMP of pesticides,

* Corresponding author. Tel.: + 223207092 00/+1 4186562131 ; fax: +22320709201.

E-mail address: alphonsesingbo@gmail.com, a.singbo@cgiar.org (A.G. Singbo). distinguishing damage abatement inputs and productive inputs. Both studies report overuse of pesticides. Non-parametric approaches are an attractive alternative to parametric approaches, since a functional form of the distance or production function does not have to be assumed. Furthermore, the non-parametric Data Envelopment Analysis (DEA) approach allows for simultaneous measurement of technical efficiency and the VMPs of inputs. However, despite their clear advantages, non-parametric approaches have rarely been used in the literature to address this question. Oude Lansink and Silva (2004) used DEA to estimate the VMP of pesticides and to investigate the impact of productive inputs on the VMP of pesticides. Skevas, Oude Lansink, and Stefanou (2012) use DEA to represent a production technology that considers both pesticides' dynamic impacts and production uncertainty (accounted through variability in climatic conditions) in their effort to investigate the performance of Dutch arable farms. Their results show that ignoring the effects of variability in production conditions may lead to an overestimation of farmers' inefficiency. A shortcoming of previous nonparametric approaches is their failure to perform statistical inference on the estimated VMP's of pesticides. Recently bootstrap methods (Simar \& Wilson, 2008) have been proposed in the literature to enable statistical inference in DEA models. However, these methods have not yet been applied in the estimation of VMPs from DEA models.

Against the background of the foregoing, the objective of this study is to estimate technical efficiency and the shadow price values (VMP) 
of pesticides and other inputs in vegetable production. The VMPs are estimated from different DEA models, each determining technical efficiency and VMP on a different part of the frontier. Statistical inference on technical efficiency and VMPs is obtained using a smooth bootstrap procedure. Also, the impact of different inputs on the VMP of pesticides is investigated. This paper contributes to the literature by being the first to employ a bootstrap method for performing statistical inference of technical efficiency and for the value of marginal products (VMPs) in order to overcome the main drawback of DEA approach. The method is applied to vegetable production in Benin.

The remainder of this paper is organized as follows. Section 2 presents the DEA models and the bootstrap technique to perform statistical inference on the VMPs of pesticides and other inputs. The case study of vegetable production in Benin is described in Section 3, followed by the presentation of the empirical results in Section 4. Concluding remarks follow in the last section.

\section{Input distance function with damage abatement inputs}

\subsection{DEA models incorporating damage abatement inputs}

Consider a sample of $N$ farms which produce $Q$ outputs from $P$ purchased productive inputs and $A$ purchased damage abatement inputs (pesticides). Let $y \in \mathfrak{R}_{+}^{Q}, x \in \mathfrak{R}_{+}^{P}$, and $z \in \mathfrak{R}_{+}^{A}$ denote vectors of nonnegative outputs, non-negative productive inputs and non-negative damage abatement inputs, respectively. The production technology for a decision making unit (DMU) is fully represented by the input requirement set:

$L(\boldsymbol{y})=\left\{(\boldsymbol{x}, \boldsymbol{z}) \in \mathfrak{R}_{+}^{P} \times \Re_{+}^{A} \mid(\boldsymbol{x}, \boldsymbol{z})\right.$ can produce $\left.\boldsymbol{y}\right\}$

which represents the set of all feasible combinations of vectors of productive and damage abatement inputs given a vector of outputs $\boldsymbol{y}$. A non-parametric representation of $L(\boldsymbol{y})$ is:

$L(\boldsymbol{y})=\left\{(\boldsymbol{x}, \boldsymbol{z}): \boldsymbol{Y}^{\prime} \lambda \geq y_{i}, \boldsymbol{X}^{\prime} \lambda \leq x_{i}, \boldsymbol{Z}^{\prime} \lambda \leq z_{i}, \mathbf{I}^{\prime} \lambda=\mathbf{1}, \lambda \geq \mathbf{0}\right\}$

where $\boldsymbol{Y}$ is the $(N \times Q)$ matrix of observed outputs, $y_{i}$ is the vector of observed outputs of farm $i, \boldsymbol{X}$ is the $(N \times P)$ matrix of observed productive inputs, $x_{i}$ is the vector of productive inputs used by farm $i, \boldsymbol{Z}$ is the $(N \times A)$ matrix of observed damage abatement inputs, $z_{i}$ is the vector of damage abatement inputs used by farm $i$; $\lambda$ is a $(N \times 1)$ vector of intensity variables (farm weights) and I is the $(N \times 1)$ unit vector. We assume that (1) satisfies the standard regularity conditions: possibility of inactivity, no free lunch, strong input and output disposability, ${ }^{1}$ closedness of $L(\boldsymbol{y})$ and variable returns to scale (VRS) (Färe, 1988, p. 35; Färe \& Grosskopf, 1990; Fukuyama \& Weber, 2002). The VRS condition $\left(\mathbf{I}^{\prime} \lambda=1\right)$ ensures that increased amounts of inputs do not necessarily lead to a proportional increase of the amount of outputs. Technical efficiency is defined as the ability of a farm to use the minimum feasible amounts of productive and/or damage abatement inputs to produce a given level of output. Hence technical efficiency is measured relative to production possibilities characterized by $L(\boldsymbol{y})$. The Shephard input distance function is defined as:

$D^{I}(x, z, y)=\sup \{\gamma>0:(x / \gamma, z / \gamma) \in L(y)\}$

where $\gamma$ is the input sub-vector space technical efficiency scores for the DMU. The input distance function can reflect joint production of multiple outputs, while duality between the input distance function and the cost function allows retrieval of the input shadow prices. In order to compute the technical efficiency of an individual input,

\footnotetext{
1 Since we applied our models to small scale farms we maintain strong disposability assumption for fixed inputs because strong disposability implies weak disposability, but the converse does not hold (see Färe, Grosskopf, \& Lovell, 1994, p. 38 for details). We experimented by assuming weak disposability of fixed inputs as in Skevas et al. (2012) and found that the technical inefficiency scores are relatively close but greater than or equal to the ones obtained from imposing strong disposability.
}

sub-vector technical efficiency measures are introduced to generate technical efficiency measures of a subset of inputs rather than for the entire vector of inputs, holding all other inputs and outputs constant. Four input-oriented models are constructed for measuring technical efficiency, i.e. they contract inputs in four different directions.

The first model (Model 1) measures technical efficiency by radially contracting all productive inputs (fixed and variable inputs) and damage abatement inputs equiproportionately, while keeping outputs constant. In this model, we assumed that producers can adjust all inputs. This standard radial measure is incapable of identifying the technical efficiency of individual input use, since such a measure treats the contribution of productive and abatement inputs to technical efficiency equally. The technical efficiency score obtained from this model is a radial measure and is restrictive in that it assumes that inefficient producers can be brought to the frontier only by shrinking all inputs. In other words, this model assumes that a technically inefficient producer will have the same degree of input overuse for all inputs. The second model (Model 2) measures technical efficiency by radially contracting only variable productive inputs equiproportionately, given the fixed inputs, the damage abatement inputs and outputs. The third model (Model 3) measures technical efficiency by radially contracting all damage abatement inputs in equal proportions, given the productive inputs (variable and fixed inputs) and the output level. The fourth model (Model 4) is a variation of the Russell technical efficiency measure that allows for non-proportional contractions in each input. This model allows for non-proportional reductions in each subset of inputs, allowing for different technical efficiency scores of productive inputs and damage abatement inputs. This is equivalent to the non-radial notion of input technical efficiency, as discussed by Kopp (1981). The main purpose of having four different input-oriented models (radial and non-radial) is to have four separate sets of shadow price calculations of pesticide and productive inputs at four different points on the production frontier. This procedure was also applied by Ball, Lovell, Nehring, and Somwaru (1994) and Oude Lansink and Silva (2004). It helps to show the variation in the results according to each point on the frontier. The general form of the four models is given by:

$$
\begin{aligned}
& \min _{\gamma_{i}, \lambda} \gamma_{j i} \\
& \text { s.t. } \\
& Y \lambda \geq y_{i} \\
& X \lambda \leq \gamma_{k i} x_{i} \\
& Z \lambda \leq \gamma_{l i} z_{i} \\
& \mathbf{I} \lambda=1 \\
& \lambda \geq 0
\end{aligned}
$$

where $\gamma_{k}$ and $\gamma_{l}$ are the input sub-vector space technical efficiency scores for farm $i$. The specification of each of the four models is summarized in Table 1.

Table 1

Specification of the models.

\begin{tabular}{lll}
\hline Models & $\begin{array}{c}\text { Technical efficiency } \\
\text { for choice variables }\end{array}$ & $\begin{array}{l}\text { Objective } \\
\text { function }\end{array}$ \\
\hline $\begin{array}{l}\text { Model 1: } \\
\text { Radial technical efficiency in the full } \\
\text { input space }\end{array}$ & $\gamma_{k i}=\gamma_{l i}=\gamma_{1 i}$ & $\min _{\gamma_{1 i}, \lambda} \gamma_{1 i}$ \\
$\begin{array}{l}\text { Model 2: } \\
\text { Radial technical efficiency in the } \\
\text { productive input subspace }\end{array}$ & $\gamma_{k i}=\gamma_{2 i}, \gamma_{l i}=1$ & $\min _{\gamma_{2 i}, \lambda} \gamma_{2 i}$ \\
$\begin{array}{l}\text { Model 3: } \\
\text { Radial technical efficiency in the } \\
\text { damage abatement input subspace }\end{array}$ & $\gamma_{k i}=1, \gamma_{l i}=\gamma_{3 i}$ & $\min _{\gamma_{3 i}, \lambda} \gamma_{3 i}$ \\
$\begin{array}{l}\text { Model 4: } \\
\text { Non-radial technical efficiency } \\
\text { measure }\end{array}$ & $\gamma_{k i} \neq \gamma_{l i}$ & $\min _{\gamma_{k i}, \gamma_{l i}, \lambda}\left(\gamma_{k i}+\gamma_{l i}\right) / 2$ \\
\hline
\end{tabular}


A set of dual variables for each observation is obtained from each model. These dual variables are used to generate the value of the marginal product (shadow price) of each input. Using the first derivative of output with respect to inputs, the marginal products of each input for output $q$ are given by (Ball et al. 1994; Oude Lansink \& Silva, 2004):

$$
\begin{aligned}
\mathrm{MP}_{p q i}^{m} & =\frac{\partial y_{q i}}{\partial x_{p i}}=-\frac{\partial \gamma_{m i} / \partial x_{p i}}{\partial \gamma_{m i} / \partial y_{q i}}, \quad m=1, \ldots, 4 ; \quad p=1, \ldots, P ; \\
q & =1, \ldots, Q ; \quad i=1, \ldots, N,
\end{aligned}
$$$$
\mathrm{MP}_{a q i}^{m}=\frac{\partial y_{q i}}{\partial z_{a i}}=-\frac{\partial \gamma_{m i} / \partial z_{a i}}{\partial \gamma_{m i} / \partial y_{q i}}, \quad m=1, \ldots, 4 ; \quad a=1, \ldots, A ;
$$$$
q=1, \ldots, Q ; \quad i=1, \ldots, N,
$$

where $\mathrm{MP}_{p q i}^{m}$ is the marginal product of the productive input $p$ for output $q$ and for observation $i$ estimated from model $m, \mathrm{MP}_{a q i}^{m}$ is the marginal product of the damage abatement input $a$ for output $q$ and for observation $i$ estimated from model $m$ and $\gamma_{\mathrm{mi}}$ is the technical efficiency score for the $i$ th observation in model $m(=1, \ldots, 4)$. The quantities $\partial \gamma_{m i} / \partial \chi_{p i}, \partial \gamma_{m i} / \partial z_{a i}$ and $\partial \gamma_{m i} / \partial y_{q i}$ are the dual variables in model $\mathrm{m}(=1, \ldots, 4)$ associated with the constraints on the productive input $p$, the damage abatement input $a$ and the output $q$. The value of the marginal product of each input is obtained as:

$\mathrm{SV}_{p q i}^{m}=w^{q} \mathrm{MP}_{p q i}^{m}$,

$\mathrm{SV}_{a q i}^{m}=w^{q} \mathrm{MP}_{a q i}^{m}$,

where $w^{q}$ is the observed price of output $q, \mathrm{SV}_{p q i}^{m}$ is the value of the marginal product of the productive input $p$ for output $q$ and for observation $i$ estimated from model $m, S V_{a q i}^{m}$ is the value of the marginal product of the damage abatement input $a$ for output $q$ and for observation $i$ estimated from model $m$. Each model provides an estimate of the shadow prices of each input at a particular point on the frontier. Since our model includes multiple outputs, the values of the marginal product are calculated for each output separately. If farmers maximize profits, then the shadow prices of a given input is the same across outputs (Varian, 2002, p. 566). However, in practice the shadow prices computed from the two outputs will not coincide. To circumvent this problem, revenue shares of the $Q$ outputs are used to compute a weighted (using revenue shares as weight) average of the shadow prices for each input of observation $i$ in each model as follows:

$\mathrm{SV}_{p i}^{m}=\sum_{q=1}^{Q}\left(\rho_{q i} \times \mathrm{SV}_{p q i}^{m}\right)$,
$\mathrm{SV}_{a i}^{m}=\sum_{q=1}^{Q}\left(\rho_{q i} \times \mathrm{SV}_{a q i}^{m}\right)$,

where $\rho_{q i}$ is the revenue share of output $q$ for observation $i, \mathrm{SV}_{p i}^{m}$ is the weighted average value of the marginal product of the productive input $p$ for observation $i$ estimated from model $m, \mathrm{SV}_{a i}^{m}$ is the weighted average value of the marginal product of the damage abatement input $a$ for observation $i$ estimated from model $m$.

The extent to which damage abatement inputs are underused or overused is inferred from a comparison of the shadow prices and market prices. Shadow prices are greater (lower) than market prices for inputs that are underused (overused).

The technical relation between damage abatement inputs and productive inputs is investigated using the four models outlined above. The approach used is to first generate shadow prices of the productive inputs using each model. Next, one damage abatement input constraint is increased by one unit and new shadow prices of the productive inputs are generated for each model. This constraint perturbation is done for each of $A$ damage abatement inputs. Comparison of the shadow prices of the productive inputs from the perturbed model and the original shadow prices provides information on the local technical relation between these inputs and a particular damage abatement input (Oude Lansink \& Silva, 2004). If increasing a damage abatement input increases (reduces) the shadow price of another input, then the two inputs are local complements (substitutes). Furthermore, increasing the pesticides constraint is expected to decrease the shadow price of pesticides because the value of the marginal product of pesticide is positive but declining in pesticide use and can be seen from Eq. (5) which comes from the first order condition of cost minimization problem.

\subsection{Smooth bootstrap procedure}

Simar and Wilson $(1998,2000)$ methodologically studied the statistical properties of nonparametric envelopment estimators and developed a single-smooth bootstrap algorithm which can be used to examine the statistical properties of technical efficiency scores generated through DEA. As the statistical properties of the frontier are obtained from finite samples, the corresponding measures of technical efficiency are sensitive to the sampling variations of the obtained frontier. Hence, the DEA estimators could be biased upward (Simar \& Wilson, 1998, 2008).

The full-sample homogenous smooth bootstrap is a consistent way to analyze the sensitivity of technical efficiency scores relative to the sampling variations of the estimated frontier. As stated by Simar and Wilson (1998, 2000), we assume a data-generating process where farms randomly deviate from the underlying true frontier in a radial direction. We apply the full-sample homogenous smooth bootstrap to overcome the possible statistical noise that may affect the measurement of technical efficiencies and shadow price of pesticides. Therefore, the model accounts for the effects of statistical noise due to measurement error and statistical noise (e.g. variability in production conditions). In this paper, we subsequently estimate the biascorrected technical efficiency scores along with the shadow prices from the bootstrap sample. Ninety-five percent confidence intervals are also generated for technical efficiency scores and shadow prices. The algorithm is given in Appendix.

\section{Case study: vegetable production in Benin}

Vegetables are essential for a healthy and balanced diet in Sub Saharan Africa. However, vegetable crops are susceptible to pests and diseases and subject to increasing use of pesticides. Williamson et al. (2008) found that vegetable producers in Benin used larger volumes of pesticides than vegetable farmers in Ghana and Ethiopia and reported higher frequency of application (every 3-5 days insecticides spraying) than cotton farmers. Previous research also showed that small scale vegetable farmers did not receive adequate agricultural extension services and were lacking knowledge in pesticide use (Ngowi, Mbise, Ijani, London, \& Ajayi, 2007).

The problems associated with pesticide use in developing countries have been widely documented (see Dinham, 2003 for an overview). Inappropriate and excessive use of pesticides has negative consequences for the efficiency of the abatement of the intended pest. Moreover operator and consumer health, farm livestock, soil organisms, wildlife, vegetation and the natural environment are negatively affected (Williamson et al., 2008). Availability and affordability of pesticides was a major concern for many vegetable producers; hence underuse of categories of pesticides has been likely too. In Benin, pesticides are traded in formal and informal markets where both approved and banned pesticides are sold.

The empirical economics literature on pesticide use in vegetable production in Benin, however, has paid little attention to the VMP of pesticides and factors determining this VMP. Most 
Table 2

Descriptive statistics.

\begin{tabular}{|c|c|c|c|}
\hline Variable & Unit & Mean & Std. deviation \\
\hline \multicolumn{4}{|l|}{ Quantities } \\
\hline $\begin{array}{l}\text { Aggregate output for } \\
\text { traditional vegetables }\end{array}$ & $10^{6}$ FCFA & 2.521 & 6.519 \\
\hline $\begin{array}{l}\text { Aggregate output for } \\
\text { non-traditional vegetables }\end{array}$ & $10^{6}$ FCFA & 1.203 & 2.016 \\
\hline $\mathrm{N}$-fertilizer & $10^{5}$ FCFA & 2.342 & 4.209 \\
\hline Other inputs & $10^{5}$ FCFA & 1.049 & 1.702 \\
\hline Land area & hectare & 0.638 & 1.509 \\
\hline Labor & $10^{2}$ man-hour & 3.195 & 1.156 \\
\hline Capital & $10^{5}$ FCFA & 6.034 & 9.423 \\
\hline Water & $10^{6}$ liter & 5.124 & 12.287 \\
\hline Insecticides & $10^{4}$ FCFA & 3.328 & 4.795 \\
\hline Other pesticides & $10^{4}$ FCFA & 4.134 & 10.372 \\
\hline \multicolumn{4}{|l|}{ Prices } \\
\hline $\begin{array}{l}\text { Paasche weighted average } \\
\text { price index for traditional } \\
\text { vegetable }\end{array}$ & Index & 1.004 & 0.448 \\
\hline $\begin{array}{l}\text { Paasche weighted average } \\
\text { price index for non-traditional } \\
\text { vegetables }\end{array}$ & Index & 0.873 & 0.590 \\
\hline
\end{tabular}

Note: 1 U.S. dollar $=494.030$ FCFA in 2010 or 1 Euro $=655.957$ FCFA.

farm-level economic analysis of pesticide use has focused on costbenefit analysis and the willingness to pay for biopesticides or organically grown vegetables (Adégbola \& Singbo, 2001; Coulibaly, Cherry, Nouhoheflin, Aitchedji, \& Al-Hassan, 2006; Coulibaly, Nouhoheflin, Aitchedji, Cherry, \& Adégbola, 2011; Martin, AssogbaKomlan, Houndete, Hougard, \& Chandre, 2006; Singbo, Nouhoeflin, \& Assogba-Komlan, 2008). A major limitation of these studies is that they treat pesticides as a productive input, ignoring agronomic evidence which suggests that pesticides are a damage abatement input (Lichtenberg \& Zilberman, 1986). Hence, empirical evidence based on studies that ignore the damage abatement nature of pesticides is biased (Lichtenberg \& Zilberman, 1986).

The intensification of vegetable production in urban areas is accompanied by problems of pesticide overuse and misuse. In this regard, the efficiency of vegetable production in Sub Saharan Africa is especially important because of its intensive use of chemical inputs. As indicated by Fernandez-Cornejo (1994), the improvement in the effectiveness of input use, particularly in the case of fertilizers and pesticides, can increase farm profitability as well as alleviate health and environmental concerns. Food safety concerns about pesticide residues are pertinent in vegetables which are often consumed with little post-harvest processing.

The data used in this study were obtained through a survey among specialized vegetable producers in southern Benin in the period 20092010. The sample was selected based on the proportion of traditional and non-traditional vegetable farms in each administrative region and is representative of the urban and peri-urban vegetable producers in Benin. A sample of 136 producers of traditional and non-traditional vegetables is obtained which covers a range of farm sizes. Table 2 reports the descriptive statistics of key variables.

The variable list contains two aggregate outputs (traditional vegetables and non-traditional vegetables ${ }^{2}$ ), six productive inputs ( $\mathrm{N}$ fertilizer, land, labor, capital, water and other variable inputs,) and two damage abatement inputs (insecticides and other pesticides). Traditional vegetables consist of tomato, solanum plants, okra, pepper, amaranth, corchorus, bitterleaf, African basil, cockscomb and onion. Non-traditional vegetables consist of lettuce, cabbage, courgette, cucumber, beet, carrot, radish, turnip, French bean, melon, squash, watermelon, celery, chicory, chives, coriander, dill, fennel,

\footnotetext{
2 Traditional vegetables refer to all plant species that have been used by communities for several generations and are integrated as part of the cultural habits (Achigan-Dako, Pasquini, \& Assogba-Komlan, 2009).
}

Table 3

Average technical efficiency scores and confidence intervals $(n=136 ; B=2000)$.

\begin{tabular}{|c|c|c|c|c|}
\hline \multirow[t]{2}{*}{ Models } & \multirow[t]{2}{*}{$\begin{array}{l}\text { Initial } \\
\text { efficiency } \\
\text { scores }\end{array}$} & \multirow{2}{*}{$\begin{array}{l}\text { Bias } \\
\text { corrected } \\
\text { efficiency } \\
\text { scores }\end{array}$} & \multicolumn{2}{|c|}{$\begin{array}{l}95 \text { percent } \\
\text { confidence } \\
\text { interval }\end{array}$} \\
\hline & & & $\begin{array}{l}\text { Lower } \\
\text { bound }\end{array}$ & $\begin{array}{l}\text { Upper } \\
\text { bound }\end{array}$ \\
\hline $\begin{array}{l}\text { Model 1: radial technical efficiency } \\
\text { measure of all inputs }\end{array}$ & 0.849 & 0.724 & 0.716 & 0.726 \\
\hline $\begin{array}{l}\text { Model 2: radial technical } \\
\text { efficiency measure of } \\
\text { productive inputs }\end{array}$ & 0.652 & 0.362 & 0.341 & 0.371 \\
\hline $\begin{array}{l}\text { Model 3: radial technical efficiency } \\
\text { measure of pesticides }\end{array}$ & 0.635 & 0.314 & 0.297 & 0.327 \\
\hline Model 4: Russell-type Productive & 0.879 & 0.787 & 0.779 & 0.789 \\
\hline $\begin{array}{l}\text { technical efficiency Pesticides } \\
\text { measure }\end{array}$ & 0.656 & 0.439 & 0.412 & 0.454 \\
\hline
\end{tabular}

garden mint, leek, overripe, parsley, rocket and thyme. The quantity of output is measured as the sum of the revenues from traditional and non-traditional crops, respectively. It is important to notice that we selected a subsample from the original sample of producers, in particular those who produce both outputs because accounting for zero values in DEA model is problematic. Variable productive inputs represent $\mathrm{N}$-fertilizer, water and other variable inputs. $\mathrm{N}$-fertilizer represents the cost of purchased nitrogen. Water consists of the quantity of water used. Other variable input consists of seeds and other miscellaneous expenses. Fixed inputs are labor, land and capital. Labor is assumed to be fixed input, as a large share of a total labor consists of family labor and hired labor and is measured in man-hours. Land represents the total area under vegetable crops and is measured in hectares. Capital consists of machinery and equipment and is measured in replacement cost.

In the study area, insecticides dominated chemical pest management, reflecting not only the serious problems of insect attack in vegetable production, but also the availability and relatively low cost of many older generation insecticides. Other pesticides consist of fungicides, herbicides, nematicides, acaricides, fumigant, rodenticides and biopesticides. We limit our study to two categories of pesticides to avoid zero values in the damage abatement inputs. The data set exhibits considerable variation, especially with respect to the quantity of damage abatement inputs where standard deviations exceed the means and the difference between the minimum and maximum is relatively large.

\section{Results and discussion}

\subsection{Technical efficiency analysis}

The results of each model for the smoothed bootstrap with 2000 bootstrap replications for each observation are reported in Table 3. The results consist of the average initial technical efficiency scores, the average bias-corrected technical efficiency estimates and the lower and upper bounds of the 95 percent confidence intervals of the average technical efficiency. The technical efficiency scores generated from the four models suggest a significant amount of technical inefficiency. Since the initial DEA estimates in all models are outside the 95 percent confidence intervals (meaning that the bias estimates are large relative to the standard error estimates), the bias-corrected technical efficiency estimates are preferred over the initial estimates (Simar \& Wilson, 2008). In each model, the initial technical efficiency scores for the 136 units yield an average uncorrected technical efficiency score of 0.635 (Model 3) to 0.879 (Model 4), while the bootstrap model generates an average bias-corrected score of 0.314 (Model 3 ) to 0.787 (Model 4). The 95 percent confidence intervals are of moderate length. The average bias-corrected technical efficiency score of Model 
Table 4

Average shadow values of inputs and 95 percent bootstrap confidence intervals $(n=136 ; B=2000)$.

\begin{tabular}{|c|c|c|c|c|c|c|c|c|c|}
\hline \multirow[t]{2}{*}{ Inputs } & \multirow[t]{2}{*}{ Market price } & \multicolumn{2}{|l|}{ Model 1} & \multicolumn{2}{|l|}{ Model 2} & \multicolumn{2}{|l|}{ Model 3} & \multicolumn{2}{|l|}{ Model 4} \\
\hline & & Shadow price & 95 percent $\mathrm{CI}$ & Shadow price & 95 percent $\mathrm{CI}$ & Shadow price & 95 percent $\mathrm{CI}$ & Shadow price & 95 percent $\mathrm{CI}$ \\
\hline \multicolumn{10}{|l|}{ Productive inputs } \\
\hline $\mathrm{N}$-fertilizer & $1^{\mathrm{a}}$ & 0.83 & {$[0.28 ; 2.61]$} & 0.70 & {$[0.27 ; 2.57]$} & 0.68 & {$[0.28 ; 2.67]$} & 1.07 & {$[0.42 ; 2.82]$} \\
\hline Other inputs & $1^{\mathrm{a}}$ & 0.54 & {$[0.22 ; 1.40]$} & 0.60 & {$[0.26 ; 1.47]$} & 0.62 & {$[0.26 ; 1.41]$} & 0.73 & {$[0.22 ; 1.99]$} \\
\hline Land area & $5.00^{\mathrm{b}}$ & 2.00 & {$[0.53 ; 7.35]$} & 2.21 & {$[0.57 ; 7.21]$} & 2.17 & {$[0.55 ; 7.48]$} & 2.86 & {$[0.51 ; 8.76]$} \\
\hline Labor & $1.19^{c}$ & 3.24 & {$[1.36 ; 6.26]$} & 3.92 & {$[1.42 ; 6.62]$} & 3.06 & {$[1.42 ; 6.34]$} & 3.64 & {$[1.54 ; 7.42]$} \\
\hline Capital $^{\mathrm{d}}$ & - & 1.43 & {$[0.18 ; 3.90]$} & 1.41 & {$[0.19 ; 3.55]$} & 1.97 & {$[0.19 ; 6.32]$} & 3.30 & {$[1.06 ; 6.11]$} \\
\hline Water & $0.00^{\mathrm{e}}$ & 0.52 & {$[0.09 ; 1.63]$} & 0.92 & {$[0.13 ; 1.68]$} & 0.54 & {$[0.13 ; 1.37]$} & 1.07 & {$[0.28 ; 3.56]$} \\
\hline \multicolumn{10}{|c|}{ Damage abatement inputs } \\
\hline Insecticides & $1^{\mathrm{a}}$ & 0.36 & {$[0.21 ; 0.71]$} & 0.43 & {$[0.21 ; 0.75]$} & 0.36 & {$[0.22 ; 0.62]$} & 0.0006 & {$[0.00 ; 0.004]$} \\
\hline Other pesticides & $1^{\mathrm{a}}$ & 0.47 & {$[0.13 ; 1.27]$} & 0.45 & {$[0.14 ; 1.33]$} & 0.43 & {$[0.15 ; 1.31]$} & 0.0025 & {$[0.00 ; 0.012]$} \\
\hline
\end{tabular}

Note: CI: Confidence intervals, 1 U.S. dollar $=494.030$ FCFA in 2010 or 1 Euro $=655.957$ FCFA.

a Prices of N-fertilizer, other inputs, insecticides and other pesticides are set to one because these inputs are aggregated and measured in FCFA. For instance, if a producer wants to buy 1 FCFA of fertilizer, he/she has to pay 1 FCFA.

b Land price is based on the state land price per ha (Law no. 164/PC/MFAEP-EDT of 11 September, 1964) since the majority of land cultivated in urban and peri-urban areas is the property of the state ( $10^{6} \mathrm{FCFA}$ ). In fact, Benin is still a transition country in terms of its land policy with heterogeneous nature of land tenure arrangements (Le Meur, 2008).

c Labor price per man-hour is the price for permanent hired labor (FCFA) and is calculated from the survey data.

d - A market price of capital is not calculated as we should compute a price index for capital which is not comparable to a real market price level.

e Water price is set to be zero as the cost for irrigation equipment is included in capital and the labor used for irrigation is included in labor.

3 suggests a relatively higher amount of technical inefficiency than Models 1 and 2. Since Model 3 measures technical efficiency in the use of pesticides, this indicates that vegetable farms in the sample are less efficient in the use of pesticides. This implies that by using pesticides efficiently, the vegetable producers would be able to reduce their pesticide use by almost 69 percent, on average, keeping output and productive inputs constant. Also, the bias-corrected technical efficiency score of Model 4 indicates, on average, a higher amount of technical inefficiency in the use of pesticides than in the use of productive inputs, given the output level. Since the estimated technical efficiency score of pesticides in Models 3 and 4 is lower than the technical efficiency in Model 1, the results suggest that the application of pesticides is more difficult to manage for vegetable producers than the use of productive inputs such as fertilizers, labor, land, capital and water. These findings can be explained by the fact that in the conventional agricultural production system, the technical efficiency of pesticides is generally more dependent on weather, soil conditions and pest incidence than the technical efficiency of productive inputs (Oude Lansink \& Silva, 2004). The formulation and the method of application also have greater influence on the technical efficiency of pesticides on the size of the target pest population than the choice of active ingredient (van Emden \& Service, 2004).

\subsection{Analysis of shadow values and input relations}

The estimation of the input distance function allows us to generate shadow prices of damage abatement inputs for each producer, along with their confidence intervals. In order to get the shadow values of each productive unit, we use expressions (6) and (7) under the hypothesis that the shadow prices of outputs are equal to their observed market prices as suggested by Ball, Lovell, Luu, and Nehring (2004) and Färe and Grosskopf (1990). Table 4 reports the bootstrap sample average of the shadow values of all productive and damage abatement inputs and the corresponding 95 percent confidence intervals. Shadow values of productive inputs (pesticides) in Model 2 are smaller (larger) than their values in Models 1 and 3. The differences between the shadow values of Model 2 versus Models 1 and 3 reflect the different points at the frontier at which the shadow prices are evaluated. This is because shadow prices in model 2 are evaluated at the point on the frontier that reflects the minimum quantity of productive inputs required for producing a given bundle of vegetable outputs and the quantity of pesticide use. Overall, shadow prices of productive inputs in Model 4 are larger than their respective values in the other models.
In Models 1, 2 and 3, the shadow price of fertilizer was found to be lower than the market price, which suggests overuse of fertilizer. For example, in Model 2, where performance was evaluated in the productive input subspace, vegetable producers' return for each additional FCFA of fertilizer use was 0.70 FCFA, which suggests that fertilizer is less productive. An explanation of the low shadow price of fertilizer is that a continuous and intensive vegetable production practice is observed on poor sandy soils with a large use of nutrients (Drechsel, Graefe, Sonou, \& Cofie, 2006). An additional hectare of land yielded at least $2.00 \times 10^{6}$ FCFA of revenue, which suggests a high competition for urban and peri-urban farmland. However, the shadow prices of land are significantly lower than the market price, which implies overuse of land in vegetable farming.

The average shadow price of labor in all models was found to be significantly higher than the market price, implying underuse of labor. For each additional hour of labor, producers' return ranged from $3.06 \times 10^{2}$ FCFA (model 3) to $3.92 \times 10^{2}$ FCFA (Model 2).

The shadow price of water in all four models is higher than the market price, indicating underuse of water. This result implies that the value of the marginal product of irrigation exceeds the cost of irrigation, meaning that water was not optimally used at the farm level. This result is consistent with the finding of Danso, Drechsel, Akinbolu, and Gyiele (2003) in West Africa showing that manual irrigation (the most common method of irrigation) in vegetable production needs to be carried out with high frequency, leading to underuse. However, the increased use of irrigation in vegetable production may be attributed to risk aversion by producers related to the probability of droughts (Henry \& Bowen, 1981), as access to water is a crucial requirement for year-round vegetable production.

From an additional FCFA of insecticides, producers' return ranged from $0.6 \times 10^{-3}$ FCFA (Model 4) to 0.43 FCFA (Model 2). The return from each additional FCFA of other pesticides was $0.25 \times 10^{-2}$ FCFA (Model 4) to 0.47 (Model 1). The results imply that insecticides and other pesticides were less productive for vegetable producers. The shadow prices of insecticides and other pesticides are lower than their average market prices in all models, suggesting overuse of insecticides and other pesticides. This means that vegetable producers could increase their profitability by decreasing the use of insecticides and other pesticides. This result implies that producers are allocatively inefficient in damage abatement input use. This finding is in line with the conventional wisdom in the agricultural community that farmers overuse pesticides (Macharia, Mithofer, \& Waibel, 2011; Sexton, Lei, \& Zilberman, 2007). An explanation for excessive use of pesticides is an intensive growing systems with high yields, short rotations and thus a 
Table 5

Average differences in the shadow values of inputs and the corresponding 95 percent bootstrap confidence intervals when the insecticides and other pesticides constraints change by one unit $(n=136 ; B=2000)$.

\begin{tabular}{|c|c|c|c|c|c|c|c|c|}
\hline \multirow[t]{2}{*}{ Inputs } & \multicolumn{2}{|l|}{ Model 1} & \multicolumn{2}{|l|}{ Model 2} & \multicolumn{2}{|l|}{ Model 3} & \multicolumn{2}{|l|}{ Model 4} \\
\hline & Difference & 95 percent $\mathrm{CI}$ & Difference & 95 percent $\mathrm{CI}$ & Difference & 95 percent $\mathrm{CI}$ & Difference & 95 percent $\mathrm{CI}$ \\
\hline \multicolumn{9}{|l|}{ Insecticides } \\
\hline $\mathrm{N}$-fertilizer & 0.157 & {$[-1.80 ; 2.04]$} & 0.165 & {$[-1.63 ; 1.93]$} & 0.187 & {$[-1.81 ; 1.81]$} & -0.026 & {$[-1.90 ; 1.86]$} \\
\hline Other inputs & -0.002 & {$[-0.91 ; 1.08]$} & -0.024 & {$[-1.00 ; 0.95]$} & -0.048 & {$[-1.03 ; 0.91]$} & -0.044 & {$[-1.43 ; 1.28]$} \\
\hline Land area & -0.31 & {$[-6.19 ; 5.34]$} & -0.047 & {$[-5.84 ; 4.72]$} & 0.039 & {$[-6.15 ; 4.75]$} & -0.017 & {$[-6.13 ; 5.88]$} \\
\hline Labor & 0.540 & {$[-2.78 ; 3.58]$} & -0.709 & {$[-3.74 ; 3.78]$} & 0.514 & {$[-3.60 ; 3.69]$} & -0.283 & {$[-3.57 ; 2.73]$} \\
\hline Capital & 0.815 & {$[-1.93 ; 3.70]$} & -0.034 & {$[-2.26 ; 2.58]$} & -0.702 & {$[-5.07 ; 2.24]$} & -0.378 & {$[-3.57 ; 2.50]$} \\
\hline Water & 0.308 & {$[-1.08 ; 1.43]$} & -0.128 & {$[-0.92 ; 1.63]$} & 0.268 & {$[-0.77 ; 1.55]$} & -0.212 & {$[-2.07 ; 1.14]$} \\
\hline Insecticides & $-0.344^{* *}$ & {$[-0.70 ;-0.19]$} & $-0.402^{* *}$ & {$[-0.68 ;-0.18]$} & $-0.323^{* *}$ & {$[-0.58 ;-0.17]$} & $-0.0004^{\mathrm{a}}$ & {$[-0.004 ; 0.0003]$} \\
\hline Other pesticides & 0.067 & {$[-0.76 ; 0.86]$} & 0.046 & {$[-0.80 ; 0.96]$} & 0.028 & {$[-0.90 ; 0.90]$} & 0.0003 & {$[-0.009 ; 0.008]$} \\
\hline \multicolumn{9}{|l|}{ Other pesticides } \\
\hline $\mathrm{N}$-fertilizer & -0.060 & {$[-1.93 ; 1.82]$} & 0.005 & {$[-1.57 ; 1.77]$} & 0.002 & {$[-1.87 ; 1.82]$} & -0.049 & {$[-1.56 ; 1.83]$} \\
\hline Other inputs & 0.31 & {$[-0.74 ; 1.03]$} & 0.025 & {$[-0.85 ; 0.75]$} & 0.006 & {$[-1.01 ; 0.84]$} & -0.057 & {$[-1.37 ; 1.17]$} \\
\hline Land area & 0.101 & {$[-5.31 ; 5.26]$} & -0.042 & {$[-5.46 ; 5.75]$} & 0.206 & {$[-5.60 ; 4.97]$} & 0.348 & {$[-5.81 ; 6.12]$} \\
\hline Labor & 0.435 & {$[-2.73 ; 3.34]$} & -0.652 & {$[-3.19 ; 3.81]$} & 0.215 & {$[-3.48 ; 3.81]$} & 0.099 & {$[-3.12 ; 3.06]$} \\
\hline Capital & 0.843 & {$[-2.18 ; 3.10]$} & -0.031 & {$[-2.33 ; 2.52]$} & -0.589 & {$[-4.97 ; 2.39]$} & 0.170 & {$[-3.10 ; 3.44]$} \\
\hline Water & 0.33 & {$[-0.95 ; 1.55]$} & -0.005 & {$[-0.84 ; 1.46]$} & 0.452 & {$[-0.62 ; 1.77]$} & 0.19 & {$[-1.73 ; 1.92]$} \\
\hline Insecticides & 0.032 & {$[-0.31 ; 0.34]$} & -0.088 & {$[-0.38 ; 0.21]$} & -0.019 & {$[-0.30 ; 0.21]$} & -0.00001 & {$[-0.0025 ; 0.002]$} \\
\hline Other pesticides & $-0.465^{* *}$ & {$[-1.27 ;-0.12]$} & $-0.448^{* *}$ & {$[-1.34 ;-0.13]$} & $-0.426^{* *}$ & {$[-1.30 ;-0.14]$} & $-0.00252^{\mathrm{a}}$ & {$[-0.012 ; 0.00007]$} \\
\hline
\end{tabular}

** Significance at 5 percent level.

a Significance at 20 percent level.

high use of insecticides, herbicides, fungicides, nematicides as well as pest resistance against pesticides (de Kort, 1993; Kortenhoff, 1993). As pesticides are used in a prophylactic way to prevent anticipated infestations, the overuse of pesticides may kill pest species as well as beneficial species. Destruction of a pest's natural enemies often leads to rapid resurgence of the pest or to introduction of secondary pests, which necessitates more treatments (de Kort, 1993). In all four models the results also show that more than 97 percent of vegetable producers in the sample overuse the damage abatement inputs (insecticides and other pesticides). The magnitude of the outcome varies by model and shadow values may take a range of values in reality, depending on which model applies.

Based on the estimation results of the linear programming problem in (4), we performed a further analysis of technical relation between inputs. Table 5 reports the differences in the shadow values of productive and damage abatement inputs resulting from increasing separately by one unit the constraint of each pesticide. The 95 percent confidence intervals are also presented in Table 5 . In general, the impact of an increase in each damage abatement input on the shadow value of a productive input is not significant at the 5 percent significance level. This result implies that there is no evidence of technical relations between productive and damage abatement inputs. This result contrasts with Oude Lansink and Silva (2004) who found evidence of strong technical relationships between both types of inputs. It should be noted though that Oude Lansink and Silva (2004) did not make the bias-correction using a bootstrap approach.

As expected, in all four models, the shadow price of insecticides decreases significantly when the insecticide constraint is increased by one unit. The same result is found for other pesticides.

In sum the results in Table 5 suggest no evidence of technical interdependence between pesticide use and productive inputs. This is the challenge in most of empirical analysis of the economics of pesticides where the estimated form of such relationships can be critical for farm-level decision making (Hall \& Moffitt, 2002; Marsh, Huffaker, \& Long, 2000; Saphores, 2000; Sexton et al., 2007). As indicated by Skevas et al. (2013), a reason for the lack of technical interdependence in this study could be the failure to account for the dynamics of pesticide use where increased pesticide pressure on soil organisms may affect fertilizer use through a decrease in the soil's nutritional characteristics.

These results could be of interest in defining an efficient point of pesticide use in vegetable production. From the above results, the main problem with the use of pesticides could be related to the mix of approved and banned pesticides. As indicated by Snelder, Masipiqueña, \& de Soo, (2008) in the case of Philippines, a mechanism is needed to control the use and sale of restricted and banned pesticides as most of the pesticides used in vegetable production are freely sold in stores and markets. Since, the market of approved pesticides (selective pesticides) for vegetable production is missing, policy makers should make such products available to producers, while a distribution channel is required for low-cost application products. Due to lack of training in pesticide use, vegetable producers do not always respect the re-entry periods after spraying and essential harvest intervals are not known. In this respect, integrated pest management addressing the issues of pesticides use and alternatives must be adjusted and reinforced to the case of vegetable products with emphasis on cost-effective pest-control methods for covering the investment risks. However, its success is strongly related to a good extension service in the early stage (van Lenteren, 1993).

\section{Conclusions}

This study uses different DEA models to estimate the technical efficiency and VMP of pesticides and other inputs. Additionally, the impact of inputs on the value of the VMP of pesticides is determined. The homogenous smoothed bootstrap method is used to determine confidence intervals of technical efficiency scores and VMPs.

Results show that vegetable producers have a lower technical efficiency in the use of pesticides than in the use of other inputs. Also, results suggest that vegetable producers overuse insecticides and other pesticides. The overuse of pesticides can be attributed to the characteristics of the vegetable production system and may also point at high risk aversion of farmers, i.e. farmers overuse pesticides in order to reduce the risks of pests and diseases. The study shows that there is no evidence of technical interdependence between pesticides and productive inputs, i.e. other inputs have no statistically significant impact on the VMP of pesticides. The overuse of pesticides lead to economic losses, i.e. producers can increase their profitability by reducing pesticides use. The results suggest the need for a more rational pesticide application, i.e. by using information about the onfarm costs and benefits of pesticides. The government may support the adoption of more rational pesticide use practices by providing better information to farmers through extension services. Also, the government may pursue a policy that aims to reduce the dependence 
of producers on pesticides. Integrated pest management addressing the issues of pesticides usage and alternatives may be adjusted and reinforced to the case of vegetable products with emphasis on costeffective pest-control methods.

\section{Acknowledgments}

This paper was produced when the first author was a Ph.D. researcher at Wageningen University. Financial support from the Dutch government scholarship through the Netherlands fellowship programs is gratefully acknowledged. The fieldwork was facilitated by the excellent support of the National Institute for Agricultural Research of Benin (INRAB) and enumerators.

\section{Appendix}

Bootstrap algorithm used for generating bias corrected technical efficiency scores and estimating shadow prices and their confidence intervals

In this appendix, we present the algorithm used for Model 1, which can be extended and applied to the other three models. To start with, we assume that the distribution of efficiency is homogeneous over the input-output space. The algorithm for obtaining a set of bootstrap technical efficiency estimates $\left\{\hat{\gamma}_{b}^{*}(x, z, y) \mid b=1, \ldots, B\right\}$ and a set of bootstrap shadow prices involves the following steps:

Part 1. Computing the original and biased corrected technical efficiency scores, along with their confidence intervals

(1) From the original data set $\mathcal{X}_{n}$, compute the technical efficiency, $\hat{\gamma}_{i}=\hat{\gamma}\left(x_{i}, z_{i}, y_{i}\right) \forall i=1, \ldots, n . \hat{\gamma}_{i} \geq 0$, assuming variable returns to scale (VRS).

(2) Select a value of the smoothing parameter (the bandwidth), $h$, using the normal reference rule (Simar \& Wilson, 2008, p. 459).

(3) Generate a naïve bootstrap sample $\beta_{1}^{*}, \ldots, \beta_{n}^{*}$ by drawing independently, uniformly and with replacement from the set of $D_{2 n}$, where $D_{2 n}=\left\{\hat{\gamma}_{1}, \ldots, \hat{\gamma}_{n},-\hat{\gamma}_{1}, \ldots,-\hat{\gamma}_{n}\right\}$.

(4) Draw the error term $\varepsilon_{i}^{*}, i=1, \ldots, n$ independently from the probability density kernel function and compute $\beta_{i}^{* *}=\beta_{i}^{*}+h * \varepsilon_{i}^{*}$ for each $i=1, \ldots, n$.

(5) For each $i=1, \ldots, n$, compute $\beta_{i}^{* * *}=\overline{\beta^{*}}+\frac{\beta_{i}^{* *}-\overline{\beta^{*}}}{\left(1+h^{2} \sigma_{\beta}^{-2}\right)^{1 / 2}}$, where $\overline{\beta^{*}}=n^{-1} \sum_{i=1}^{n} \beta_{i}^{*}$ and $\sigma_{\beta}^{2}=n^{-1} \sum_{i=1}^{n}\left(\beta_{i}^{*}-\overline{\beta^{*}}\right)^{2}$.

(6) Compute the bias corrector $\gamma_{i}^{*}$, where $\gamma_{i}^{*}=\left\{\begin{array}{l}-\beta_{i}^{* * * \forall} \forall \beta_{i}^{* * *}<0, \\ \beta_{i}^{* * *} \text { otherwise. }\end{array}\right.$.

(7) Define the bootstrap sample $\chi_{n}^{*}=\left\{\left(x_{i}^{*}, y_{i}\right) \mid i=1, \ldots, n\right\}$, where $x_{i}^{*}=\gamma_{i}^{*} \hat{x}^{\partial}\left(y_{i}\right)=\gamma_{i}^{*} \hat{\gamma}_{i}^{-1} x_{i}$.

(8) Compute the technical efficiency estimate $\hat{\gamma}^{*}(x, y)$ for the fixed point $(x, y)$, using the reference set $\chi_{n}^{*}$.

(9) Repeat steps (3)-(8), B(2000) times to obtain a set of bootstrap estimates $\left\{\hat{\gamma}_{l}^{*}(x, y) \mid b=1, \ldots, \boldsymbol{B}\right\}$.

(10) Calculate the bias of the original estimator as follows: $\operatorname{bias}\left(\hat{\gamma}_{i}\right)=$ $\boldsymbol{B}^{-1} \sum_{b=1}^{\boldsymbol{B}} \hat{\gamma}_{i, b}^{*}-\hat{\gamma}_{i}$.

(11) Construct a bias-corrected estimator of the true value of $\gamma$ by computing $\hat{\hat{\gamma}}_{i}^{* *}=\hat{\gamma}_{i}-\operatorname{bias}\left(\hat{\gamma}_{i}\right)=2 \hat{\gamma}_{i}-\boldsymbol{B}^{-1} \sum_{b=1}^{\boldsymbol{B}} \hat{\gamma}_{i, b}^{*}$.

(12) Generate the confidence interval of level 0.95 for $\gamma_{i}$ by computing $\hat{\gamma}_{i}-c_{0.025} \leq \gamma_{i} \leq \hat{\gamma}_{i}-c_{0.975}$, where $c_{a}$ denotes the ath-quantile of the sampling distribution of $\left(\hat{\gamma}_{i}^{*}-\hat{\gamma}_{i}\right)$. Finding $c_{\alpha / 2}$ and $c_{(1-\alpha) / 2}$ is carried out by sorting the values of $\left(\hat{\gamma}_{i}^{*}-\hat{\gamma}_{i}\right)$ in increasing order and then deleting the $\left(\frac{\alpha}{2} \times 100\right)$ percent of the elements at either end of the sorted list.

\section{Part 2. Computing the shadow values and their confidence intervals}

(13) For each set of bootstrap estimates $\left\{\hat{\gamma}_{l}^{*}(x, y) \mid b=1, \ldots, \boldsymbol{B}\right\}$ obtained in (9), generate the dual variable quantities $\partial \gamma_{i} / \partial x_{p i}$, $\partial \gamma_{i} / \partial z_{a i}$ and $\partial \gamma_{i} / \partial y_{q i}$ (Eq. (5)) and for each output category, compute the value of the marginal product of each input using Eq. (6).

(14) Using output revenue shares as weights, generate a set of bootstrap estimates of the average of the shadow prices for each input as indicated in Eq. (7).

(15) From the set of bootstrap estimates of the average of the shadow prices for each input in (14), construct the 95 percent level of confidence intervals as in the case of the efficiency scores in (12).

Note: In the case of Model 4, we simultaneously estimate technical efficiencies for both productive inputs and pesticides by using two different smooth parameters in (2) to each input sub-set to generate the bootstrap sample.

\section{References}

Achigan-Dako, E. G., Pasquini, M. W., \& Assogba-Komlan, F. (2009). Inventory and use of traditional vegetables: Methodological framework. In E. G. Achigan-Dako, et al. (Eds.), Traditional vegetables in Benin: Diversity, distribution, ecology, agronomy, and utilisation (pp. 9-51). Cotonou, Benin.

Adégbola, Y. P., \& Singbo, A. G. (2001). Analyse socio-économique de la filière des biopesticides en cultures maraîchères au Bénin p. 30. Cotonou, Benin: PAPA/INRAB and IITA

Ball, V. E., Lovell, C. A. K., Luu, H., \& Nehring, R. F. (2004). Incorporating environmental impacts in the measurement of agricultural productivity growth. Journal of Agricultural and Resource Economics, 29(3), 436-460.

Ball, V. E., Lovell, C. A. K., Nehring, R. F., \& Somwaru, A. (1994). Incorporating undesirable outputs into models of production: An application to US agriculture. Review of Agricultural and Environmental Studies (Cahiers d'Economie et Sociologie Rurales), 31, $60-74$

Coulibaly, O., Cherry, A., Nouhoheflin, T., Aitchedji, C. C., \& Al-Hassan, R. (2006). Vegetable producer perceptions and willingness to pay for biopesticides. Journal of Vegetable Science, 12(3), 27-42.

Coulibaly, O., Nouhoheflin, T., Aitchedji, C., Cherry, A., \& Adégbola, P.(2011). Consumers' perceptions and willingness to pay for organically grown vegetables. International Journal of Vegetable Science, 17(4), 349-362.

Danso, G. K., Drechsel, P., Akinbolu, S. S., \& Gyiele, L. A. (2003). Review of studies and literature on the profitability and sustainability of urban and peri-urban agriculture (FAO final report, PR 25314). Ghana: IWMI.

de Kort, C. A. D. (1993). Recent advances in insecticides and growth regulators. In J. C. Zadoks (Ed.), Modern crop protection: developments and perspectives (pp. 37-51). Wageningen, The Netherlands: Wageningen Pers.

Dinham, B. (2003). Growing vegetables in developing countries for local urban populations and export markets: Problems confronting small-scale producers. Pest Management Science, 59, 575-582.

Drechsel, P., Graefe, S., Sonou, M., \& Cofie, O. O. (2006). Informal irrigation in urban West Africa: An overview 35 p. (Research report 102). Sri Lanka: IWMI.

Färe, R. (1988). Fundamentals of production theory. Lecture notes in economics and mathematical systems p. 163. Berlin: Springer-Verlag.

Färe, R., \& Grosskopf, S. (1990). A distance function approach to price efficiency. Journal of Public Economics, 43, 123-126.

Färe, R., Grosskopf, S., \& Lovell, C. A. K. (1994). Production frontiers (296 p.). New York: Cambridge University Press.

Fernandez-Cornejo, J. (1994). Nonradial technical efficiency and chemical input use in agriculture. Agricultural and Resource Economics Review, 23(1), 11-21.

Fukuyama, H., \& Weber, W. L. (2002). Estimating output allocative efficiency and productivity change: Application to Japanese banks. European Journal of Operational Research, 137, 177-190.

Hall, D. C., \& Moffitt, L. J. (2002). Modeling for pesticide productivity measurement. In D. C. Hall, \& L. J. Moffitt (Eds.), Economics of pesticides, sustainable food production and organic food markets (pp. 21-35). London: Elsevier Science.

Henry, M. S., \& Bowen, E. (1981). A method for estimating the value of water among sectors of a regional economy. Southern Journal of Agricultural Economics, 12, 125132.

Kopp, R. J. (1981). The measurement of productive efficiency: Reconsideration. The Quarterly Journal of Economics, 96(3), 477-503.

Kortenhoff, A. (1993). Developments in the use of pesticides. In J. C. Zadoks (Ed.), Modern crop protection: Developments and perspectives (pp. 3-10). Wageningen, The Netherlands: Wageningen Pers.

Le Meur, P.-Y. (2008). Information on land: A common asset and strategic resource, the case of Benin, Making decentralization work: 147 p. 22. UK: Russell Press.

Lichtenberg, E., \& Zilberman, D. (1986). The econometrics of damage control: Why specification matters. American Journal of Agricultural Economic, 68, 261-273.

Macharia, I., Mithofer, D., \& Waibel, H. (2011). Indirect and external costs of pesticide use in the vegetable sub-sector in Kenya. In D. Mithöfer, \& D. Waibel(Eds.), Vegetable production and marketing in Africa: Socio-economic research (pp. 227-242). CAB International.

Marsh, T. L., Huffaker, R. G., \& Long, G. E. (2000). Optimal control of vector-virus-plant interactions: The case of potato leafroll virus net necrosis. American Journal of Agricultural Economics, 82(3), 556-569. 
Martin, T., Assogba-Komlan, F., Houndete, T., Hougard, J. M., \& Chandre, F. (2006). Efficacy of mosquito netting for sustainable small holders' cabbage production in Africa. Journal of Economic Entomology, 99(2), 450-454.

Ngowi, A. V. F., Mbise, T. J., Ijani, A. S. M., London, L., \& Ajayi, O. C. (2007). Smallholder vegetable farmers in Northern Tanzania: Pesticide use practices, perceptions, cost and health effects. Crop Protection, 26, 1617-1624.

Oude Lansink, A., \& Carpentier, A. (2001). Damage control productivity: An input damage abatement approach. Journal of Agricultural Economics, 52(3), 11-22.

Oude Lansink, A., \& Silva, E. (2004). Non-parametric production analysis of pesticides use in the Netherlands. Journal of Productivity Analysis, 21, 49-65.

Saphores, J-D. M. (2000). The economic threshold with a stochastic pest population: A real options approach. American Journal of Agricultural Economics, 82(3), 541-555.

Sexton, S. E., Lei, Z., \& Zilberman, D. (2007). The economics of pesticides and pest control. International Review of Environmental and Resource Economics, 1, 271-326.

Simar, L., \& Wilson, P. W. (1998). Sensitivity analysis of efficiency scores: How to bootstrap in nonparametric frontier models. Management Science, 44(1), 49-61.

Simar, L., \& Wilson, P. W. (2000). A general methodology for bootstrapping in nonparametric frontier models. Journal of Applied Statistics, 27, 779-802.

Simar, L., \& Wilson, P. W. (2008). Statistical inference in nonparametric frontier models: Recent developments and perspectives. In H. O. Fried, K. C. A. Lovell, \& S. S. Schmidt (Eds.), The measurement of productive efficiency and productivity growth (pp. 421521). New York: Oxford University Press Inc
Singbo, A., Nouhoeflin, T., \& Assogba-Komlan, F. (2008). Facteurs socio-économiques déterminant la lutte contre les ravageurs des légumes en zones urbaines au sud Bénin. In L. Parrot, et al. (Eds.), Agricultures et développement urbain en Afrique subsaharienne: Environnement et enjeux sanitaires (pp. 1-11). Paris: L'Harmattan.

Skevas, T., Oude Lansink, A., \& Stefanou, S. (2012). Measuring technical efficiency in the presence of pesticide spillovers and production uncertainty: The case of Dutch arable farms. European Journal of Operational Research, 223, 550-559.

Skevas, T., Stefanou, S. E., \& Oude Lansink, A. (2013). Do farmers internalise environmental spillovers of pesticides in production? Journal of Agricultural Economics, 64(3), 624-640.

Snelder, D. J., Masipiqueña, M. D., \& de Soo, G. R. (2008). Risk assessment of pesticide usage by smallholder farmers in the Cagayan Valley (Philippines). Crop Protection. 27, 747-762.

van Emden, H.F., \& Service, M.W.(2004). Pest and vector control(349 p.). UK: Cambridge University Press.

van Lenteren, J. C. (1993). Integrated pest management: The inescapable trend. In J. C. Zadoks (Ed.), Modern crop protection: Developments and perspectives (pp. 217225). Wageningen, The Netherlands: Wageningen Pers.

Varian, H.R. (2002). Intermediate microeconomics: A modern approach (688 p.) (6th ed.) New York, USA: W.W. Norton \& Company.

Williamson, S., Ball, A., \& Pretty, J. (2008). Trends in pesticide use and drivers for safer pest management in four African countries. Crop Protection, 27, 13271334. 